\title{
Is Periodic Abstinence from Dairy Products for Half a Year, Detrimental to Bone Health of Children and Adolescents?
}

\author{
Rodopaios $\mathrm{NE}^{1 *}$, Manolarakis $\mathrm{GE}^{1}$, Peppas $\mathrm{C}^{2}$ and \\ Kafatos $\mathbf{A}^{1}$ \\ ${ }^{1}$ Department of Preventive Medicine and Nutrition Unit, \\ School of Medicine, University of Crete, Greece \\ ${ }^{2}$ Department of Surgeon, Metropolitan Hospital, Athens \\ *Corresponding author: Nikolaos E. Rodopaios, \\ Preventive Medicine and Nutrition Unit, School of \\ Medicine, University of Crete, Greece
}

Received: December 01, 2017; Accepted: December 22, 2017; Published: December 29, 2017

\begin{abstract}
The question of "What's the best diet for children and adolescents which ensures their optimum bone health?" has triggered this review study of all nutritional habits including the Christian Orthodox Church's diet with its particular periods of fasting. In order to evaluate the abstinence from dairy products in childhood and adolescence for more than 180 days per year, we assessed the relative knowledge on vegans and vegetarians in relation to calcium intake. We researched the world-wide published experience as well as studies focused on Christian Orthodox Church's fasting and its contribution to bone health status in children and teenagers with at least one year follow-up randomized controlled trials. During the last 30 years, more than 120 published studies all over the world dispute the generalization that milk consumption during childhood and adolescence relates to "strong bones". World-wide research experience on vegans and vegetarians reveals that non-diary food resources of calcium fortify the bones, ensure their integrity and development and that calcium daily intake, essential for the bone health, and can be gained from foods other than dairy. Abstinence from dairy products in childhood and adolescence for about 180 days per year-as proposed by the Christian Orthodox Church- seems to act as a means to bone integrity and optimal development.
\end{abstract}

Keywords: Milk; Dairy; Children; Adolescents; Fast

\section{Abbreviations}

AF: All Fasting Periods; BMC: Bone Mineral Content; BMD: Bone Mineral Density; CaD: Calcium Intake Diary; COC: Christian Orthodox Church; EAR: Estimated Average Requirement; IOM: Institute of Medicine; NF: Never Fasted; PF: Partially Fasted; RDI: Recommended Daily Intake; s-BAP: Alkaline Phosphatase; s-CTX: C-Terminal Telopeptides Of Type I Collagen; s-OC: Serum Osteocalcin; WHO: World Health Organization.

\section{Introduction}

Proper nutrition is important for the development and conservation of the bone mass. $80-90 \%$ of the Bone Mineral Content (BMC) is formed by calcium and phosphorus [1], along with other important molecules and elements (proteins, magnesium, copper, iron) and vitamins (A, C, D, K) [2].

Milk is broadly consumed because of its high nutritional value. It contains various elements such as bioactive peptides, calcium, and growth factors that interfere to the bone metabolism stages, namely bone turnover [3].

The Estimated Calcium Average Requirement (EAR) for the adolescent ranges between 800 to $1050 \mathrm{mg} /$ day while the Recommended Daily Intake (RDI) is $1000-1300 \mathrm{mg} /$ day; it's also well understood that EAR as well RDI vary under certain conditions as in pregnancy, lactation, menopause and aging [4].

For more than two decades, USA recommends to children and adults the intake of calcium for prevention of osteoporosis [1,5-8]. They suggest the dairy servings as the best way for that, depending on age, for 4-8 years old is 3 servings and 9-18 years old, 4 servings daily. Three servings of dairy provide $828 \mathrm{mg}$ calcium and 4 servings $1104 \mathrm{mg} \mathrm{Ca}$ [9].

In the USA over 120 food products are calcium-fortified. Therefore taking the recommended portions of diary daily plus the calcium from non dairy products far exceeds the RDI intake of calcium. It is also amazing that although the dietary intake of calcium ranks first around the world, representing the $72 \%$ of global dietary calcium intake [10], osteoporosis and bone fractures rates are high as they range between 700 and 1000 incidents per 100000 population annually $[11,12]$. Excessive calcium intake has been questioned on its efficacy in preventing osteoporosis and its potentially negative effects in health [13-17].

Recent epidemiological studies in women [18], children and adolescents [19-22], have questioned the efficacy of dairy products and other calcium-containing products for the good health of the bones [23]

World Health Organization (WHO) recommendations for the prevention of osteoporosis highlight the "calcium paradox" and suggest a minimum intake of 400-500 mg/day of calcium from all sources for individuals above 50 who live in countries with high rate of bone fractures [24]. Furthermore, WHO concludes that "there is no chance to globally approximate the calcium intake for the general population". This statement also includes children and adolescents. 
Table 1: Fasting of the Christian Orthodox Church (COC) [28-30].

\begin{tabular}{|c|c|c|}
\hline FASTING & DAYS & PERIODS OF FASTING \\
\hline LENT & 41 & From a Clean Monday to Saturday of Lazarus \\
\hline EASTER WEEK & 6 & From Holy Monday to Saturday \\
\hline CHRISTMAS & 40 & From November 15 through December 24 \\
\hline ASSUMPTION & 14 & From 1 to August 15 \\
\hline HOLY APOSTLES* & $0-30$ ** & On the next day Sunday of All Saints up to June 28, the eve of the feast of Saints Peter and Paul \\
\hline DAILY & 3 & $\begin{array}{c}\text { January } 5 \text { (Eve of Epiphany) } \\
\text { August } 29 \text { (the decapitation of John the Baptist) } \\
\text { September } 14 \text { (Exaltation of the Holy Cross) }\end{array}$ \\
\hline $\begin{array}{l}\text { EVERY WEDNESDAY AND } \\
\text { FRIDAY }\end{array}$ & $55-63$ & $\begin{array}{l}\text { All Wednesdays and Fridays of the year, apart from those already in the periods of fasting and absolute or free } \\
\text { periods }\end{array}$ \\
\hline DAY TOTAL & $\begin{array}{c}159-197 \\
\text { SD:178 } \pm 19\end{array}$ & \\
\hline
\end{tabular}

* So named because it precedes the two apostolic feasts: the Apostles Peter and Paul, June 29 and "Synaxis (Bevy) of the 12 Apostles," June 30.

** The duration of this fasting period is undefined, because the launch depends on the moveable feast of Easter.

On the other hand, European and UK reports suggest dietary reference intake of calcium through dairy products between 800 and $1300 \mathrm{mg} /$ day for all individuals -USA included- for their whole life [25].

Skeletal health indexes such those of bone growth as well of biological maturity of bony structures can be determined through correlation between Bone Mineral Density (BMD) and/or Bone Mineral Content (BMC) outcomes and calcium intake from milk and dairy products [25]. The Institute of Medicine (IOM) in order to assess the importance of calcium and vitamin $\mathrm{D}$ intake determined the optimum Dietary Reference Intake (DRI) [26].

According to Recommended Dietary Allowances (RDA) recommendations, $700 \mathrm{mg}$ of calcium is the optimum daily dosage for children between 1 and 3 years old, whereas $1000 \mathrm{mg}$ for those of 4-8 years old. Adolescents need higher calcium levels, no less than 1300mg per day [27].

However, prospective epidemiological studies have raised questions about the effectiveness of the use of dairy products in the promotion of bone health [28]. Over the past two decades an increasing number of studies it has been carried out on religious fasts and their impact on human health [27]. The Christian Orthodox Church (COC) diet proposes entirely different dietary habits that are worth to be mentioned because through alternating time-fixed fasting periods they achieve the optimal balance in an admittedly healthy nutritional pattern: the Mediterranean diet.

COC recommends abstaining from dairy, meat, and eggs for about 180 days per year (159-197, SD: 178 \pm 19 ) and instead of 155 days/year from fish for adults and children (Table 1).

For that reason, it may be considered as periodic vegetarianism although seafood allowed in all fasting periods [31-35].

Low consumption of dairy, meat and egg products leads to reduced intake of saturated fats, while the use of olive oil in large quantities has shown positive effects on the prevention of chronic diseases [36]. In addition, COC fasts as nutritional health-promotive habits [37,38], are still the main characteristics of Mediterranean diet in Greece [39-41]. The objective of this study is to review the existing literature on the effects of consumption of dairy products and total dietary calcium intake on bone integrity in children and adolescents, primarily to assess whether the evidence supports the following:

(1) Which one of the two nutritional habits promotes the optimum bone growth during childhood and adolescence: a daily consumption of 3-4 servings of dairy products, or a periodic fasting that includes calcium from non-dairy foods?

(2) Does the statement "the recommended servings of dairy products is the optimal choice for promoting bone health and integrity in contrast to other sources of food or supplements containing calcium" seem to be valid?

(3) Has the 180-day abstinence from dairy products per year, as suggested by the COC, negative effects on bone growth in children and adolescents?

\section{Methods}

The MEDLINE, COCHRANE, EMBASE and PUBMED databases were searched. Articles not included in those databases and studies on vegetarian diets as well as studies from the Christian Orthodox Church on fasting were also searched.

Keywords used were: dairy, dairies, dairy products, vegan, fast, fasting, plus bones, Bone Mineral Density (BMD), Bone Mineral Content (BMC), osteoporosis, osteopenia, including only studies and reports to humans, children and teenagers, aging above 3 years-old, published in English language, from 1990 to January 2017.

The research focused on age, sex, and race of the participants and also on the activity level and the pubertal status. Other factors such as socioeconomic status, exposure to the sun or caffeine consumption didn't be taken into consideration.

As changes in BMD develop slowly [42] we focused on trials and studies having at least one-year follow-up.

Finally, our search yielded to 12 cross-sectional studies; 7 longitudinal prospective studies, 3 randomized and one case-control study.

\section{Results}

We studied 22 selected randomized controlled trials of milk and calcium intake for children and adolescents (Table 2).

Kardinaal et al. in cross-sectional study investigated the 
Table 2: Characteristics of the 22 selected randomized controlled trials of milk and calcium intake for children and adolescents.

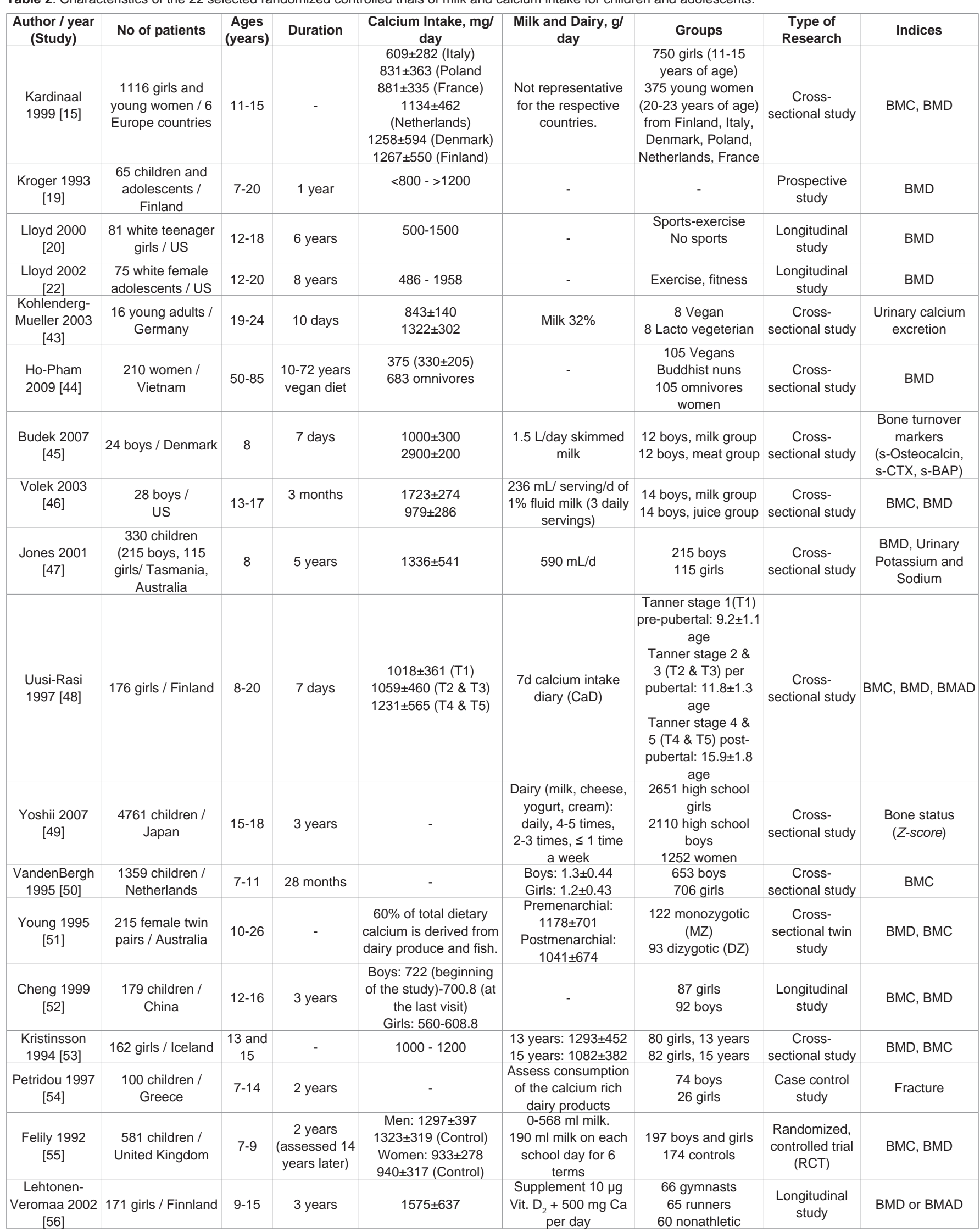




\begin{tabular}{|c|c|c|c|c|c|c|c|c|}
\hline $\begin{array}{l}\text { Welten } 1994 \\
\qquad[57]\end{array}$ & $\begin{array}{l}182 \text { children / } \\
\text { Netherlands }\end{array}$ & 13 & 15 years & $\begin{array}{l}\text { Boys: } 1100-1435 \\
\text { Girls: } 941.4-1204\end{array}$ & $\begin{array}{l}80 \% \text { of the calcium } \\
\text { intake is supplied by } \\
\text { dairy products }\end{array}$ & $\begin{array}{l}84 \text { boys } \\
98 \text { girls }\end{array}$ & $\begin{array}{l}\text { Longitudinal } \\
\text { study }\end{array}$ & BMD \\
\hline $\begin{array}{l}\text { Chan GM } \\
1995[58]\end{array}$ & 48 white girls / US & 11 & 1 year & $\begin{array}{l}\text { Control: } 728 \pm 321 \\
\text { Dairy: } 1437 \pm 366\end{array}$ & $\begin{array}{c}\text { Dairy products } \\
\text { weekly }(1200 \mathrm{mg} \mathrm{Ca})\end{array}$ & $\begin{array}{l}24 \text { Control group } \\
24 \text { Dairy group }\end{array}$ & $\begin{array}{l}\text { Randomized, } \\
\text { controlled trial } \\
(\mathrm{RCT})\end{array}$ & BMC, BMD \\
\hline $\begin{array}{c}\text { Cadogan } 1997 \\
\text { [59] }\end{array}$ & $\begin{array}{l}82 \text { white girls / } \\
\text { United Kingdom }\end{array}$ & 12.2 & 18 months & $\begin{array}{l}\text { Control: } 703 \\
\text { Milk: } 1125\end{array}$ & Milk group: $568 \mathrm{~mL} / \mathrm{d}$ & $\begin{array}{l}38 \text { Control } \\
44 \text { Milk }\end{array}$ & $\begin{array}{c}\text { Open } \\
\text { Randomized } \\
\text { intervention } \\
\text { trial }\end{array}$ & $\mathrm{BMD}, \mathrm{BMC}$ \\
\hline $\begin{array}{c}\text { Chryssochoou } \\
2010 \text { [60] }\end{array}$ & $\begin{array}{l}323 \text { boys and } 286 \\
\text { girls / Greece }\end{array}$ & $5-15^{1 / 2}$ & $31 / 2$ years & $\begin{array}{l}1134 \pm 28(\mathrm{TF}) \\
1040 \pm 28(\mathrm{PF}) \\
1090 \pm 59(\mathrm{NF})\end{array}$ & $\begin{array}{l}451 \pm 14(\mathrm{TF}) \\
383 \pm 14(\mathrm{PF}) \\
427 \pm 30(\mathrm{NF})\end{array}$ & $\begin{array}{c}\text { Total fastening (TF) } \\
12,1 \% \\
\text { Partial fastening } \\
\text { (PF) } 43,3 \% \\
\text { No fastening (NF) }\end{array}$ & $\begin{array}{c}\text { Cross- } \\
\text { sectional study }\end{array}$ & Growth rate \\
\hline
\end{tabular}

association between dietary calcium intake and radial bone density among 1116 Caucasian girls (aged 11-15 years) at different levels of calcium intake in six European countries. There was no evidence of a relation between calcium intake and BMD at different levels of intake; although there was a positive association at calcium intake levels $<600 \mathrm{mg} /$ day $(6.28, \mathrm{p}=0.02)$. Nevertheless, the interaction was not significant and there was no consistent trend over intake categories. These results do not support the hypothesis that dietary calcium acts as a determinant of peak BMD in European young women, for a wide range of intake [15].

Kröger et al. studied the effect of puberty and genetic factors on the development of bone mass and density in a prospective study 65 children and adolescents (aged 7-20 years old). They didn't find any significant relationship between the increment rate of bone density and physical activity or calcium intake $(<800->1200)$ [19].

Lloyd et al. studied in two longitudinal studies the relation of exercise and BMD on teenage. The first, one (year 2000) was conducted in 81 girls [20] Cumulative sports-exercise scores between ages 12 and 18 years were associated with hip BMD at age of 18 years $(\mathrm{r}=.42)$ but not related to the total body bone mineral gain. Timeaveraged daily calcium intake ranged from 500 to $1500 \mathrm{mg}$ /day in this cohort, was not associated with hip BMD at age 18 years or with total body bone mineral gain at age 12 through 18 years.

The second study (2002) included 75 healthy white female adolescents (aged 12-18 years) sports-exercise scores were correlated with BMD at the femoral neck and shaft. Average total daily calcium intake at age 12-20 years old ranged from 486 to $1958 \mathrm{mg} /$ day and no associations $(\mathrm{p}<0.05)$ were observed between bone measurements and calcium intake [22].

Kohlenberg-Mueller et al. in a cross-sectional study focused on the vegan diet in seven women and one man 19 to 24 years old indicating that neither calcium balance nor a single bone turnover biomarker has been significantly affected. Calcium intake levels $(843 \pm 140 \mathrm{mg}$, $\mathrm{p}<0.01)$ were adequate despite the significant difference in calcium intake levels between plant foods and dairy [43].

Ho-Pham's et al. cross-sectional study compared bone health in 105 postmenopausal vegan Mahayana Buddhist nuns and 105 omnivorous postmenopausal women 50-85 years old. Nuns, which had been engaged the vegan diet at mean 33 years (range: 10-72 years), demonstrated on average very low (330 \pm 205 vs. $682 \pm 417$ $\mathrm{mg} /$ day, $\mathrm{p}<0.001 \mathrm{mg}$ ) calcium daily intake. Lumbar Spine BMD was identical in both groups $\left(0.74 \pm 0.14\right.$ vs. $0.77 \pm 0.14 \mathrm{~g} / \mathrm{cm}^{2}$; mean $\pm \mathrm{SD}$; $\mathrm{p}=0.18)$. Same results in Femoral Neck BMD (0.62 \pm 0.11 vs. $0.63 \pm 0.11$ $\left.\mathrm{g} / \mathrm{cm}^{2} ; \mathrm{p}=0.35\right)$ as well as in Body BMD results were $0.88 \pm 0.11$ vs. $0.90 \pm 0.12 \mathrm{~g} / \mathrm{cm}^{2} ; \quad(\mathrm{p}=0.31)$. Prevalence of osteoporosis ( $\mathrm{T}$ scores $\leq-2.5$ ) at the femoral neck in vegans and omnivores was $17.1 \%$ and $14.3 \%(\mathrm{p}=0.57)$, respectively. Therefore, veganism has no adverse effect on BMD [44].

In a randomized case-control study, milk intake of $1.5 \mathrm{~L} /$ day for 7 days was associated with higher calcium intake $(\mathrm{p}<0.0001)$ but decreased bone turnover in prepubertal 24 boys. Serum osteocalcin (s-OC) and C-terminal telopeptides of type I collagen (s-CTX) were significantly decreased in the milk group $(-30.9 \% ;-18.7 \%$, respectively, $\mathrm{p} \leq 0.04)$ as well as bone-specific alkaline phosphatase $(\mathrm{s}-\mathrm{BAP})(\mathrm{p}=0.06)$ [45].

Another randomized case-control prospective study examined the effects of increased milk consumption on bone (and body) composition in boys engaged with resistance training. Twenty-eight boys (13 to 17 years of age) were randomly assigned to consume, in addition to their habitual diet, 3 servings/day of $1 \%$ milk $(n=14)$ or fruit juice not fortified with calcium $(n=14)$ while followed a 12-week resistance training program. Only the "whole-body BMD" was been affected. The milk group showed two-fold greater increase than the juice group ( 0.028 vs $0.014 \mathrm{~g} / \mathrm{cm}^{2}$, respectively). Nevertheless, the juice group showed a greater increase at "whole-body BMC", after 12 weeks $(2,667 \mathrm{~g}$ vs $2,591 \mathrm{~g}$ respectively, $\mathrm{p}<0.001)$. BMD and BMC were increased in both groups after six weeks, and there was a further increase at $12^{\text {th }}$ week [46].

A cross-sectional study of 330 boys and girls aged 8 years no association was found between children's current calcium intake (1336 mg per day deriving from milk, fruit and vegetable consumption) and BMD. Only potassium and vegetable intakes, were negatively associated with total-body BMD (-0.14 and -0.15 , respectively, $\mathrm{p}<0.05$ ) [47].

A cross-sectional study of 176 Finnish girls aged 8-20 years-old had a seven-day Calcium intake Diary $(\mathrm{CaD})$. Subjects were classified into three groups according to Tanner stage: prepubertal (Tanner $1 ; \mathrm{n}=41$ ), peripubertal (Tanner 2 and $3 ; \mathrm{n}=54$ ), and postpubertal (Tanner 4 and $5 ; \mathrm{n}=81$ ). No association was found between calcium intake and bone activity variables (BMD, BMC, and BMD femoral neck), but the high level of calcium intake in all age groups of the study $\mathrm{T} 1+1018 \pm 361 \mathrm{mg} / \mathrm{d}, \mathrm{T} 3$ and $\mathrm{T} 4=1059 \pm 460 \mathrm{mg} / \mathrm{d}$ and $\mathrm{T} 4$ and $\mathrm{T} 5=1231 \pm 565 \mathrm{mg} / \mathrm{d}$ was likely to explain the lack of association. Namely, the fact that calcium intake that exceeds a certain level does not further contribute to bone mineralization [48]. 
A cross-sectional study in Central Japan's community (Mie) study the effects of dairy intake on bone health in a representative population sample of Japanese adult women $(\mathrm{n}=1252,19-80$ years-old), high-school adolescent girls $(\mathrm{n}=2651,15-18$ years-old) and boys ( $\mathrm{n}=2110,15-18$ years-old). These groups were examined according to the frequency of weekly milk consumption which was set at 4-5 times, 2-3 times and $\leq 1$ time a week. Z-score dropped as the frequency of milk intake increased in all women. Specifically, it was $103.4 \%$ for once a week intake or less, $102.3 \%$ for 2 or 3 times a week, $102.8 \%$ for 4 to 5 times a week, and $101.2 \%$ for the daily intake. Bone density of the subjects was noticeably lower in the daily intake subgroup than that of the once a week or less, although not statistically significant $(\mathrm{p}<0.1)$. This suggests that the bone density of adult women decreases as the frequency of milk intake is increasing. Also, the intake of milk did not affect the bone density of high school girls who avoided physical exercise (Z-score daily 95.3\%, $\leq 1$ time $95.2 \%,(\mathrm{p}<0.1))[49]$.

The same study included 2110 Japanese boys, study the effect of milk intake on bone density on those abstained from physical activities in comparison to those systematically exercised was similar ( $\mathrm{p}<0.1$ ). For no-exercise boys, Z-score showed a rise proportionally to the milk consumption, although the alteration was not significant (for daily milk intake was $95.9 \%$ and for $\leq 1$ time was $93.3 \%, p<0.1$ ). In those Japanese boys cheese intake showed that Z-score was lowest in the daily intake group (systematic-exercise boys: daily $99.5 \%$ and $\leq 1$ time $100.4 \%$, no-exercise boys: daily $93.6 \%$ and $\leq 1$ time $94.4 \%$, $(\mathrm{p}<0.1))$. Same results for yoghurt in no-exercise high school girls (daily $93.8 \%$ and $\leq 1$ time $95.1 \%$, $(\mathrm{p}<0.1)$ ). Lastly, the cream seems to be beneficial for the bone health of girls without physical activity $(\mathrm{p}=0.05)$ [49].

In a cross-sectional study in Netherlands examined the relation between physical activity, calcium intake from dairy products and BMC in 1359 children aged 7 to 11 years. No significant differences (in adjusted mean levels) in bone mineral content were found when "high" and "low" calcium intake groups were compared ("high" and "low" being defined by the upper and lowest decile of calcium intake). No evidence was found for any association between daily calcium intake and BMC in childhood, concluding that increased BMC was only detected in children with a high level of physical activity [50].

The study of 215 female twin pairs (122 monozygotic and 93 dizygotic) aged 10-26 years demonstrated the roles of constitutional and lifestyle factors on bone mass. $60 \%$ of total dietary calcium was derived from dairy products. In post-menarchial pairs, the detected difference in daily calcium intake level of intake $(1041 \pm 674 \mathrm{~g} /$ day $)$ was associated with a univariate fashion with a relevant difference in total body BMC, although the robust estimation was considerably smaller. Across all pairs and after adjusting for menarchial status, height, lean mass, and fat mass, the coefficient for calcium intake became $0.04-/+$ $0.09 \% / 100 \mathrm{mg}$. There were also found no associations within-pair relatively calcium intake and BMD at the lumbar or femoral sites [51]

In a 3-year prospective study of 179 Hong Kong boys and girls aged 12-13 years at baseline - reported that there was no influence of calcium intake ( $711.8 \mathrm{mg} /$ day for boys and $580.8 \mathrm{mg} /$ day for the girls) on BMD, BMC and bone mineral accretion. During the study period, mean $\mathrm{BMC}$ of the dominant forearm increased from 0.61 to 0.75 (p
$<0.001$ ) in the boys $(25 \%)$ and from 0.64 to 0.73 (p < 0.001) in the girls (12.3\%). Similarly, mean BMD of L2-L4 vertebrae was increased for both sexes from 0.63 to 0.77 ( $\mathrm{p}<0.001)$ in boys $(24.2 \%)$ and from 0.75 to $0.87(\mathrm{p}<0.001)$ in girls $(14.5 \%)$. For girls, a higher age and an advanced pubertal stage at the beginning of the study resulted in a significantly $(\mathrm{p}=0.03)$ slower rate of increase in BMC of the forearm and BMD of the lumbar spine when compared with those girls with a less advanced pubertal stage at the beginning of the study. Comparing $\mathrm{BMC}$ of the forearm and BMD of the lumbar spine among boys and girls, rates of change in boys were significantly higher than those in girls $(\mathrm{p}<0.01)[52]$.

In a study of 162 Icelandic Caucasian girls aged 13 and 15, reported a threshold effect intake on BMD of calcium intake $1293 \pm 452 \mathrm{mg} / \mathrm{d}$ in 13 year age group and $1082 \pm 382 \mathrm{mg} / \mathrm{d}$ calcium in 15 year age group (the intake of calcium from dairy products was $16.3 \%$ higher in younger girls as compared to older); above this, no further effect has been noticed. Univariate analysis showed no significant correlation between calcium intakes from milk and other dairy products and $\mathrm{BMD}$ or BMC in either age group [53].

A case-control study investigated for 2 years the relationship between dairy intake and the risk of fractures in 100 children (74 boys and 26 girls, aging 7-14 years old). They concluded that high consumption of cola sodas and noncarbonated beverages (including fruit juices) are positively and significantly associated with the probability of a fracture. On the other hand, consumption of either non-cola carbonated beverages or dairy products is unrelated. The latter is possibly due to misclassification of dairy intake or/and the fact that consumption of dairy products is generally high in adolescence and early adulthood [54].

A cohort of 581 pupils from Wales aged 7-9 investigated for the effect of milk supplement in childhood during growth on adult forearm Bone Mineral Content (BMC) and Bone Mineral Density (BMD) in a 14 years follow-up. They were randomized half of them to receive $190 \mathrm{ml}$ of milk daily (or $228 \mathrm{mg}$ of calcium) at their free school meal, regardless of that at home, on each school day for six terms in comparison to a control group given no milk. The total calcium intake in the two groups was for the Men: $1297 \pm 397,1323 \pm 319$ (Control) and for the Women: $933 \pm 278,940 \pm 317$ (Control). They found that BMD was positively associated with body weight ( $\mathrm{p}<$ 0.01 ) current intakes of calcium ( $P$ less than 0.05 ), vitamin $D$ ( $P$ less than 0.01 ) and sports activity during adolescence; inversely associated with alcohol consumption $(\mathrm{p}<0.05)$. In multiple linear regression analysis, body weight and sports activity during adolescence were stronger determinants of female BMD than was diet [55].

In a 3-year prospective study 171 Finnish girls aged 9-15 years were investigated for calcium intake $(1575 \pm 637 \mathrm{~g} /$ day $)$ and BMD measured every 6 months for 3 years. There's no significant correlation between mean dietary calcium \& vitamin D intake and BMD or BMAD at the lumbar spine or femoral neck regarding the overall study population. However, lumbar spine BMD was at $27 \%\left(0.030 \mathrm{~g} / \mathrm{cm}^{2}\right)$ greater in the highest than in the lowest vitamin $\mathrm{D}$ intake tertile in the girls with advanced sexual maturation (95\% CI: 0.004, $0.056 \mathrm{~g} / \mathrm{cm}^{2}-\mathrm{p}$ for trend for all tertiles $=0.016)$ [56].

Another 15-year longitudinal study (the "Amsterdam Growth 
and Health Study"), examined 84 males and 98 females (aged between 13 and 28). Multiple-regression analyses incorporating Calcium Intake By Body Height (CAIH), Weight-Bearing Activities (WBA), Body Weight (WT) and BMD indicated that calcium intake during adolescence and young adulthood was not a significant predictor of lumbar BMD at the age of 27 years for both sexes (males $\mathrm{p}<0.01$, females $\mathrm{p}<0.001$ ) [57].

The effects of calcium supplementation and dairy products consumption on bone and body composition were studied in 48 of pubertal girls from USA (aged 9 to 13). In this randomized intervention study, the control group consumed their usual diet $(728 \pm 321 \mathrm{mg} /$ day calcium) and the dairy group's diet was supplemented weekly with dairy products to at least $1200 \mathrm{mg}$ calcium daily $(1437 \pm 366 \mathrm{mg} /$ day $)$ over a period of 1 year. There were no differences between the two groups during the study as showed by bone mineral values (control group: $1508 \pm 167$, dairy group: $1490 \pm 291 \mathrm{gm}$ ) and lumbar spine bone density data (control: $0.665 \pm 0.077$, dairy: $0.663 \pm 0.096 \mathrm{gm} / \mathrm{cm}^{2}$ ). At the end of the year, either average lumbar spine bone density (control group: $0.748 \pm 0.084$, dairy group: $0.772 \pm 0.086$ ) or total body bone mineral content (control: $1617 \pm 152$, dairy: 1695 \pm 317 ) did not differ significantly between groups [58].

Another randomized intervention study, 82 girls of United Kingdom 12 year old girls treated with daily consumption of $568 \mathrm{ml}$ milk for 18 months follow-up. The control group received an average baseline of $150 \mathrm{ml}$ of daily milk. Both groups demonstrated 9.6\% increase for total body BMD of milk group (SD 1.9\%; 95\% confidence interval $9.0 \%$ to $10.2 \%)$ and control group $8.5 \%$ (2.7\%; $7.6 \%$ to $9.4 \%)$; $\mathrm{p}=0.017)$ and total body BMC $27.0 \%(5.8 \% ; 25.2 \%$ to $28.8 \%)$ v $24.1 \%$ (6.3\%; $22.0 \%$ to $26.1 \%) ; \mathrm{p}=0.009)$. Expressed in absolute terms, the respective increases were $0.090(0.020 ; 0.084$ to 0.096$)$ v $0.081(0.025$; 0.072 to 0.089$) \mathrm{g} / \mathrm{cm}^{2}$ for total body BMD ( $\left.=0.021\right)$ and 428 (88; 398 to 452$)$ v $391(107 ; 358$ to 430$) \mathrm{g}$ for total body BMC ( $\mathrm{p}=0.035)$. Short term increases in calcium or dairy food intake in children or adolescents may not be sufficient to sustain an increase in bone mass over several decades [59].

At last, Chryssochoou et al. in a cross-sectional study investigated the relationships between Christian Orthodox Church's fasting and overall nutrition, growth and physical activity in children and adolescents from northern Greece. Among 609 children between 5 and 15.5 years old, $12.1 \%$ of them followed All Fasting periods (AF) without consuming dairy products $(\mathrm{p}=0.056)$ during the last 3.5 years and they didn't demonstrate any significant difference in their height $(144.0 \pm 1.2 \mathrm{~cm})$ in comparison to those that Partially Fasted (PF) $(145.0 \pm 0.6 \mathrm{~cm})$ or to the Never Fasted (NF) $(145.1 \pm 0.6)(\mathrm{p}=0.730)$. These children (NF) were found to have significantly higher calcium intake than full-fastened ones ( 1.151 versus $1.037 \mathrm{mg}$, respectively, $\mathrm{p}=0,017)[60]$.

\section{Discussion}

This study summarizes the published data on calcium balance regarding different types of dietary patterns. On the other hand, it presents the current knowledge on Orthodox Christian Church's diet as she combines features of other diets in proper timing as well as in a balanced combination of food ingredients.

Benefits from Calcium consumption are well-established regardless the source. Calcium intake - as the apparent rate of calcium absorption - doesn't significantly differ between vegan (26\%) and lactovegetarian (24\%) diet [43]. These rates are consistent with other studies on calcium balance that carried out with different kinds of non- vegetarian diet: $15 \%-36 \%$ [61], 27\% [62], 16\% -21\% [63], 23\%$31 \%$ [64] and $16 \%-24 \%$ [65].

The controversy about calcium's impact on musculoskeletal metabolism and more specifically on bone density shows significant interest. Studies on dairy-free vegetarian diets showed no (statistically significant) difference in BMD or in the degree of bone loss [66].

On the other side, the "Rotterdam study" points that fruit, vegetable, and dairy pattern with $135 \mathrm{gr}$ more milk as well as $29 \mathrm{gr}$ more yogurt, is responsible for high BMD, bending strength and more stable bones and hence for reduced osteoporotic fracture risk [HR (95\% CI): 0.92 (0.89 - 0.96)] and hip fracture [HR (95\% CI): 0.81 $(0.70-0.93)]$ in women at the age of 55 [67].

Finally, others support that bone density and risk of bone fractures were found to be similar in omnivores and lacto-vegetarians $[68,69]$.

The amount of calcium uptake is inversely related to the risk of fractures. Indeed sub-Saharan people with around $200 \mathrm{mg}$ calcium daily consumption, they present lower bone fragility than those with double intake levels (i.e. Hong Kong, Singapore and Papua New Guinea) and even more than people who exceed $1000 \mathrm{mg}$ (Norway, Sweden, Denmark, USA, UK, Ireland, New Zealand, Finland, etc.). Reasons for the wide geographic variation of fracture incidence still remain unknown [70] while causality can be found in high animalderived protein intake, low vegetable and fruit intake, and low physical activity. The negative effect of menopause onto the musculoskeletal metabolism logically it should be accompanied by corresponding changes in bone density, though this has not yet been confirmed in populations where the daily calcium intake is significantly limited about $375 \mathrm{mg}$ on average per day [44].

Even calcium and vitamin D3 daily intake for vegans is $55 \%$ and $63 \%$ respectively of those of omnivores; this doesn't adversely affect bone density or the frequency of fractures. In contrast, the higher intake of animal protein and lipids is associated with more bone loss than that of vegans [66].

On the daily milk consumption or calcium supplements during childhood and adolescence, some studies support that dietary or supplementary calcium does not affect spine \& hip bone density [15,17-19,21,22,25,44,45,48,50,52,53,55,56,71-92] or bone turnover [45], even when the daily consumption of calcium exceeds $1000 \mathrm{mg}$ $[48,53,90]$.

Others studies advocate the opposite; total body BMC/BMD increase range from small [93] to significant [46,59,76,85,94-97], also they lack sufficient information about that beneficial effect.

Having on mind that the ideal vitamin D intake levels for the children and adolescents are 400-600 IU/day, alterations on its quantity as well as on that of other nutrients (such retinol) along with exercise habits could alter the effects of milk on $\operatorname{BMD}[18,87,89,98,99]$.

High intakes of calcium (>1400 mg/day) in women are associated with higher death rates from all causes and cardiovascular disease 
[100]. Indeed, higher milk intake was associated with higher mortality as disclosed by cohort studies in both sexes with higher fracture incidence in women [101]. Moreover, there's a link between habitual consumption of milk \& dairy products with increasing risk for prostate cancer [102-104].

Apart from all the above reported on calcium equilibrium and its interactions, non-animal sources of calcium such beverages from soy or rice, cereals, and fruit juices are of great biological and nutritional importance [105].

The content of oxalates or fibers (phytate/dietary) seems to be associated with low calcium intake [106-109]. Indeed, high oxalates in spinach and rhubarb show 5\% [110] and 9\% [111] absorption rates respectively, while other plant foods demonstrate higher: $41 \%$ for cabbage [112], 22\% for beans [113] or 52\% for Chinese cabbage and $48 \%$ for broccoli [114].

Regardless of vegan or lactovegetarian diet, calcium equilibrium isn't affected despite foods with high oxalates (spinach, beets), fiberrich (whole grain bread, oats) or the calcium-rich mineral water [43]. Nevertheless, adequate calcium amounts in humans can be also achieved at intake levels far below the recommended [115-118].

Over and above, calcium bioavailability is of importance. In mineral water and milk is almost the same no matter the content [119-120] as a single dose of $172 \mathrm{mg} / \mathrm{l}$ mineral water's calcium inhibits PTH secretion and bone resorption [121]. Higher bioavailability was observed in low-oxalate vegetables as broccoli, kale, cabbage and collards unlike in nuts, dried beans, and spinach $[122,123]$.

Regular weight-bearing exercise and at least a normal agerelated body weight in adolescence and young adulthood are of key importance in reaching the highest lumbar peak bone mass at the age of 27 years, regardless calcium intake [57], protein consumption or vitamin D levels [58]

Alternative nutritional lifestyles such as vegetarianism are popular the trend for any age group. An increasing rate of 2-5\% of European adult population adopts a vegetarian eating pattern [124]. Concerns about global warming and sustainable food production as well as economic concerns are important incentives for someone to become vegetarian $[105,125,126]$. Most of them are young parents who introduce their children to vegan diet [105]. Moreover, vegan teenagers live in an otherwise omnivorous family [127]; published data (even limited) report no significant effect of vegan or vegetarian diet in growth during adolescence [128].

Among these various diets and under the general acceptance of the healthy eating habits that they introduce, Christian Orthodox Church (COC) diet introduces the "rationale of measure" instead of a complete abstinence from certain kind of foods. Fish is less frequently recommended while dairy and meat products are not allowed.

These fasting periods are well-defined and applied every year. Before long periods of fasting, such the 48-day long Lent, free consumption of all kind of food for three weeks is allowed. At the third week, only dairy products and fish (except meat) are allowed. During the week that follows the end of Lent (Easter Week) and the first 12 days after the Christmas fasting (The Twelve days) any kind of food is allowed to be consummated (Table 1) [28-30].
Papadaki et al. studied data on calcium intake alterations during one week of Lent. A double portion of all foods and drinks were chemically analyzed. Mean daily calcium intake was $533 \mathrm{mg}$ all from non-dairy products. Same chemical analysis for the non-fasting week after Easter reported 966mg/day [129].

A study conducted in children who fast, show a lower than the recommended daily intake of vitamin $\mathrm{E}$ and magnesium, but not for calcium and other minerals or trace elements which did not differ significantly between fasters (partially or completely) and non-fasters. These latter are ranked higher in daily energy intake, as they consume larger amounts of animal proteins and/or saturated fatty acids [6].

\section{Conclusion}

Overall balance and bioavailability of calcium are not significantly affected by the type of diet followed by children and adolescents. Christian Orthodox Church diet with its fasting may have a favorable effect on health as it provides adequate nutrition coverage as well as protection against numerous chronic diseases. In fact, periodic abstinence since childhood from dairy products meat and eggs tends to reduce the risk for future osteoporosis as it positively affects the bone mass density.

Far away from permanent food deprivations, which are not secondary to medical directives, one can argue that COC fasting is an integrated nutritional opportunity for a healthy lifestyle.

\section{Acknowledgements}

We thank Dr. Labadarios D., Prof. Emeritus of Stellenbosch University and Prof. Extraordinaire of University of Limpopo, South Africa, for his advice on the final writing of the Article. And Dr. Tornaritis E., Founder and Chairman of the Board of the Research and Education Institute of Child Health, Arh. Kiprianou 31, 2061, Strovolos, Cyprus, for the financial coverage of the publication of the Article.

\section{References}

1. Dietary Reference Intakes for Calcium, Phosphorous, Magnesium, Vitamin D, and Fluoride. Institute of Medicine. Standing Committee on the Scientific Evaluation of Dietary Reference Intakes. Food and Nutrition Board. Washington, DC: National Academy Press. 1997.

2. Ilich JZ, Kerstetter JE. Nutrition in bone health revisited: a story beyond calcium. Journal of the American College of Nutrition. 2000; 19: 715-737.

3. Aoe S, Koyama T, Toba $\mathrm{Y}$, Itabashi A, Takada Y. A controlled trial of the effect of milk basic protein (MBP) supplementation on bone metabolism in healthy menopausal women. Osteoporosis International. 2005; 16: 2123 2128.

4. Calcium requirements. Report of an FAO/WHO Expert Group. FAO/WHO Expert Group. Rome, Food and Agriculture Organization of the United Nations, 1962 (FAO Nutrition Meetings Report Series, No. 30.

5. National Institutes of Health. Consensus Development Panel on Optima Calcium Intake. NIH Consensus Conference: optimal calcium intake. JAMA 1994; 272: 1942-1948.

6. National Institutes of Health. Osteoporosis Prevention, Diagnosis, and Therapy. NIH Consensus Statement. 2000; 17: 1-45.

7. The Food Guide Pyramid. US Department of Agriculture. Human Nutrition Information Service. Hyattsville, MD. 1996.

8. US Department of Agriculture and US Department of Health and Human Services. Nutrition and Your Health: Dietary Guidelines for Americans. 5th ed. Washington, DC. US Department of Agriculture and US Department of 
Health and Human Services. 2000 [Home and Garden Bull. No 232].

9. National Dairy Council. 2004.

10. Gerrior S. Nutrient Content of the US Food Supply. Washington, DC. US Department of Agriculture, Center of Nutrition Policy and Promotion. 2001 (Home Economics Research Report no.53).

11. Abelow BJ, Holford TR, Insogna KL. Cross-cultural association between dietary animal protein and hip fracture: a hypothesis. Calcif Tissue Int. 1992; 50: $14-18$

12. Report of a Joint Food and Agriculture Organization of the United Nations/ World Food Organization of the United Nations Expert Consultation. Human vitamin and mineral requirements. Bangkok, Thailand; September 1998.

13. Avenell A. Bone density and milk. Exercise and body size influence bone density. BMJ. 1994; 308: 1566.

14. Hegsted DM. Fractures, calcium, and the modern diet. American Journal of Clinical Nutrition. 2001; 74: 571-573.

15. Kardinaal AF, Ando S, Charles $P$, Charzewska J, Rotily M, Väänänen K, et al. Dietary calcium and bone density in adolescent girls and young women in Europe. Journal of Bone and Mineral Research. 1999; 14: 583-592.

16. Seppa K. Bone density and milk. Consider fat as well as calcium intake. BMJ. 1994; 308: 1566

17. Weinsier RL, Krumdieck CL. Dairy foods and bone health: examination of the evidence. American Journal of Clinical Nutrition. 2000; 72: 681-689.

18. Feskanich D, Willett WC, Colditz GA. Calcium, vitamin D, milk consumption, and hip fractures: a prospective study among postmenopausal women. American Journal of Clinical Nutrition. 2003; 77: 504-511.

19. Kroger H, Kotaniemi A, Kröger L, Alhava E. Development of bone mass and bone density of the spine and femoral neck--a prospective study of 65 children and adolescents. Bone and Mineral. 1993; 23: 171-182.

20. Lloyd T, Chinchilli VM, Johnson-Rollings N, Kieselhorst K, Eggli DF, Marcus $\mathrm{R}$, et al. Adult female hip bone density reflects teenage sports exercise patterns but not teenage calcium intake. Journal of Pediatrics. 2000; 106: 40-44.

21. Lloyd T, Taylor DS. Calcium intake and peak bone mass. Journal of the American Medical Women's Association. 2001; 56: 49-52.

22. Lloyd T, Beck TJ, Lin HM, Tulchinsky M, Eggli DF, Oreskovic TL, et al Modifiable determinants of bone status in young women. Bone. 2002; 30 416-421.

23. Lanou AJ, Berkow SE, Barnard ND. Calcium, dairy products, and bone health in children and young adults: a reevaluation of the evidence. Journal of Pediatrics. 2005; 115: 736-743.

24. Joint Food and Agriculture Organization of the United Nations/World Food Organization of the United Nations Expert Consultation on Diet, Nutrition, and the Prevention of Chronic Diseases. WHO Technical Report Series 916. Geneva, Switzerland: World Health Organization. 2003.

25. Whiting SJ, Healey A, Psiuk S, Mirwald R, Kowalski K, Bailey DA, et al. Relationship between carbonated and other low nutrient dense beverages and BMC of adolescents. Nutrition Research. 2001; 21: 1107-1115

26. Institute of Medicine of the National Academy of Sciences. Dietary Reference Intakes for Calcium and Vitamin D. 2011.

27. Trepanowski JF and Bloomer RJ. The impact of religious fasting on human health. Nutrition Journal 2010; 9: 57.

28. Voloudakis EB. [Book in Greek]. Vypakis Publications, Edition B, Athens, 1999.

29. Kappa D. The Fasting. According to the teaching of our Church [Book in Greek]. Publishing Bookshops of the Holy Metropolis of Limassol, 1995. ISBN: 9607048091.

30. Koutsa Symeon, Archim. The Fasting of the Church. Why, when and how we are fast [Book in Greek]. Apostoliki Diakonia, Series Theory and Practice Edition C, Athens, December 1991. ISBN: 9963794440.
31. Sarri KO, Tzanakis NE, Linardakis MK, Mamalakis GD, Kafatos AG. Effects of Greek Orthodox Christian Church fasting on serum lipids and obesity. BMC Public Health. 2003; 16: 3-16.

32. Sarri KO, Linardakis MK, Bervanaki FN, Tzanakis NE, Kafatos AG. Greek Orthodox fasting rituals: a hidden characteristic of the Mediterranean diet of Crete. British Journal of Nutrition. 2004; 92: 277-284.

33. Papadaki A, Vardavas C, Hatzis C, Kafatos A. Calcium, nutrient and food intake of Greek Orthodox Christian monks during a fasting and nonfasting week. Public Health Nutrition. 2008; 11: 1022-1029.

34. Sarri KO, Kafatos AG, Higgins $\mathrm{S}$. Is religious fasting related to iron status in Greek Orthodox Christians? British Journal of Nutrition. 2005; 94: 198-203.

35. Sarri K, Bertsias G, Linardakis M, Tsibinos G, Tzanakis N, Kafatos A. The effect of periodic vegetarianism on serum retinol and alpha-tocophero levels. International Journal for Vitamin and Nutrition Research. 2009; 79 271-280.

36. Hakim I. Mediterranean diets and cancer prevention. Archives of Internal Medicine. 1998; 158: 1169-1170.

37. White R, Frank E. Health effects and prevalence of vegetarianism. The Western Journal of Medicine. 1994; 160: 465-471.

38. Whorton JC. Historical development of vegetarianism. American Journal of Clinical Nutrition. 1994; 59: 1103S-1109S.

39. Kafatos A, Kouroumalis I, Vlachonikolis I, Theodorou C, Labadarios D. Coronary-heart-disease risk-factor status of the Cretan urban population in the 1980s. American Journal of Clinical Nutrition. 1991; 54: 591-598.

40. Sabaté J. Religion, diet and research. British Journal of Nutrition. 2004; 92 : 199-201.

41. Trichopoulou A, Kouris-Blazos A, Wahlqvist ML, Gnardellis C, Lagiou P, Trichopoulos D, et al. Diet and overall survival in elderly people. BMJ. 1995; 311: $1457-1460$

42. Heany RP. The bone-remodeling transient: implications for the interpretation of clinical studies of bone mass change. Journal of Bone and Mineral Research. 1994; 9: 1515-1523.

43. Kohlenberg-Mueller K. and Raschka L. Calcium balance in young adults on a vegan and lactovegetarian diet. Journal of Bone and Mineral Metabolism. 2003; 21: 28-33.

44. Ho-Pham LT, Nguyen PL, Le TT, Doan TA, Tran NT, Le TA, et al. Veganism, bone mineral density, and body composition: a study in Buddhist nuns. Osteoporosis International. 2009; 20: 2087-2093.

45. Budek AZ, Hoppe C, Michaelsen KF, Molgaard C. High intake of milk, but not meat, decreases bone turnover in prepubertal boys after 7 days. European Journal of Clinical Nutrition. 2007; 61: 957-962.

46. Volek JS, Gomez AL, Scheett TP, Sharman MJ, French DN, Rubin MR, et al Increasing fluid milk favorably affects BMD responses to resistance training in adolescent boys. Journal of the American Dietetic Association. 2003; 103 1353-1356.

47. Jones G, Riley MD, Whiting SJ. Association between urinary potassium, urinary sodium, current diet, and bone density in prepubertal children American Journal of Clinical Nutrition. 2001; 73: 839-844.

48. Uusi-Rasi K, Haapasalo H, Kannus P, Pasanen M, Sievänen H, Oja P, et al. Determinants of bone mineralization in 8 to 20 year old Finnish females. European Journal of Clinical Nutrition. 1997; 51: 54-59.

49. Yoshii S, Kamimotono Sh, Sawai Sh, Matsushita MB, Tanaka F, Rujkorakarn $D$, et al. Cross-sectional survey on the relationship between dairy product intake and bone density among adult women and high school students. Nutrition Research. 2007; 27: 618-624.

50. VandenBerg MF, DeMan SA, Witteman JC, Hofman A, Trouerbach WT, Grobbee DE. Physical activity, calcium intake, and BMC in children in the Netherlands. Journal of Epidemiology and Community Health. 1995; 49: 299-304.

51. Young D, Hopper JL, Nowson CA, Green RM, Sherwin AJ, Kaymakci B, et 
al. Determinants of bone mass in 10 to 26-year-old females: a twin study. Journal of Bone and Mineral Research. 1995; 10: 558-567.

52. Cheng JC, Maffulli N, Leung SS, Lee WT, Lau JT, Chan KM. Axial and peripheral bone mineral acquisition: a 3-year longitudinal study in Chinese adolescents. Eur J Pediatr. 1999; 158: 506-512.

53. Kristinsson JO, Valdimarsson O, Steingrimsdottir L, Sigurdsson G. Relation between calcium intake, grip strength and BMD in the forearms of girls aged 13 and 15. J Intern Med. 1994; 236: 385-390.

54. Petridou E, Karpathios T, Dessypris N, Simou E, Trichopoulos D. The role of dairy products and non alcoholic beverages in bone fractures among school age children. Scand J Soc Med. 1997; 25: 119-125.

55. Fehily AM, Coles RJ, Evans WD, Elwood PC. Elwood PC. Factors affecting bone density in young adults. Am J Clin Nutr. 1992; 56: 579-586.

56. Lehtonen-Veromaa MK, Möttönen TT, Nuotio IO, Irjala KM, Leino AE, Viikari JS. Vitamin D and attainment of peak bone mass among peripubertal Finnish girls: a 3-y prospective study. Am J Clin Nutr. 2002; 76: 1446-1453.

57. Welten DC, Kemper HC, Post GB, Van Mechelen W, Twisk J, Lips P, et al Weight-bearing activity during youth is a more important factor for peak bone mass than calcium intake. J Bone Miner Res. 1994; 9: 1089-1096.

58. Chan GM, Hoffman K, McMurry M. Effects of dairy products on bone and body composition in pubertal girls. J Pediatr. 1995; 126: 551-556.

59. Cadogan J, Eastell R, Jones N, Barker ME. Milk intake and bone minera acquisition in adolescent girls: randomized, controlled intervention trial. BMJ. 1997; 315: 1255-1260.

60. Chryssochoou E, Linardakis M, Chatziagorou E, Tsanakas I, Kafatos AG The effect of Christian Orthdox Church fasting on the health and growth of children and adolescents [Article in Greek]. Paediatriki. 2010; 73: 121-129.

61. McDonald JT, Margen S. Wine versus ethanol in human nutrition. III. Calcium, phosphorus, and magnesium balance. Am J Clin Nutr. 1979; 32 823-833.

62. Gallagher JC, Riggs BL. Action of 1.25-dihydroxyvitamin D3 on calcium balance and bone turnover and its effect on vertebral fracture rate Metabolism. 1990; 39: 30-34.

63. Spencer H, Norris C, Derler J, Osis D. Effect of oat bran muffins on calcium absorption and calcium, phosphorus, magnesium and zinc balance in men. J Nutr. 1991; 121: 1976-1983.

64. Hunt JR, Gallagher SK, Johnson LK, Lykken GI. High-versus low-meat diets: effects on zinc absorption, iron status, and calcium, copper, iron, magnesium, manganese, nitrogen, phosphorus, and zinc balance in postmenopausal women. Am J Clin Nutr. 1995; 62: 621-632.

65. Haack VS, Chesters JG, Vollendorf NW, Story JA, Marlett JA. Increasing amounts of dietary fiber provided by foods normalizes physiologic response of the large bowel without altering calcium balance or fecal steroid excretion. Am J Clin Nutr. 1998; 68: 615-622.

66. Ho-Pham LT, Vu BQ, Lai TQ, Nguyen ND, Nguyen TV. Vegetarianism, bone loss, fracture and vitamin D: a longitudinal study in Asian vegans and nonvegans. Eur J Clin Nutr. 2012; 66: 75-82.

67. de Jonge EA, Kiefte-de Jong JC, Hofman A, Uitterlinden AG, Rivadeneira $\mathrm{F}$, Franco $\mathrm{OH}$, et al. Dietary patterns explaining differences in bone mineral density and hip structure in the elderly: the Rotterdam Study. Am J Clin Nutr. 2017; 105: 203-211.

68. Appleby $\mathrm{P}$, Roddam A, Allen N, Key T. Comparative fracture risk in vegetarians and nonvegetarians in EPIC-Oxford. Eur J Clin Nutr. 2007; 61: 1400-1406.

69. New SA. Do vegetarians have a normal bone mass?. Osteoporos Int. 2004 15: $679-688$.

70. Prentice A. Diet, nutrition and the prevention of osteoporosis. Public Health Nutr. 2004; 7: 227-243.

71. Katzman DK, Bachrach LK, Carter DR, Marcus R. Clinical and anthropometric correlates of bone mineral acquisition in healthy adolescent girls. J Clin
Endocrinol Metab. 1991; 73: 1332-1339.

72. Lloyd T, Andon MB, Rollings N, Martel JK, Landis JR, Demers LM, et al. Calcium supplementation and BMD in adolescent girls. JAMA. 1993; 270 : 841-844.

73. Lloyd T, Martel JK, Rollings N, Andon MB, Kulin H, Demers LM, et al. The effect of calcium supplementation and Tanner stage on bone density, content and area in teenage women. Osteoporosis International. 1996; 6: 276-283.

74. Winzenberg T, Shaw K, Fryer J, Jones G. Effects of calcium supplementation on bone density in healthy children: meta-analysis of randomized controlled trials. BMJ. 2006; 333: 775-780.

75. Taha W, Chin D, Silverberg Al, Lashiker L, Khateeb N, Anhalt H. Reduced spinal BMD in adolescents of an Ultra-Orthodox Jewish community in Brooklyn. Pediatrics. 2001; 107: 79.

76. Dibba B, Prentice A, Ceesay M, Stirling DM, Cole TJ, Poskitt EM. Effect of calcium supplementation on bone mineral accretion in Gambian children accustomed to a low-calcium diet. Am J Clin Nutr. 2000; 71: 544-549.

77. Nieves JW, Golden AL, Siris E, Kelsey JL, Lindsay R. Teenage and current calcium intake are related to bone mineral density of the hip and forearm in women aged 30-39 years. Am J Epidemiol. 1995; 141: 342-351.

78. Moro M, Van der Meulen MC, Kiratli BJ, Marcus R, Bachrach LK, Carter DR Body mass is the primary determinant of midfemoral bone acquisition during adolescent growth. Bone. 1996; 19: 519-526.

79. Maggiolini M, Bonofiglio D, Giorno A, Catalano S, Marsico S, Aquila S, et al The effect of dietary calcium intake on BMD in healthy adolescent girls and young women in southern Italy. Int J Epidemiol. 1999; 28: 479-484.

80. Bonofiglio D, Maggiolini M, Marsico S, Giorno A, Catalano S, Aquila S, et al Critical years and stages of puberty for radial bone mass apposition during adolescence. Horm Metab Res. 1999; 31: 478-482.

81. Bonofiglio D, Maggiolini M, Catalano S, Marsico S, Aquila S, Giorno A, et al. Parathyroid hormone is elevated but bone markers and density are normal in young female subjects who consume inadequate dietary calcium. $\mathrm{Br} \mathrm{J}$ Nutr. 2000; 84: 111-116.

82. Matkovic V, Fontana D, Tominac C, Goel P, Chesnut CH III. Factors that influence peak bone mass formation: a study of calcium balance and the inheritance of bone mass in adolescent females. Am J Clin Nutr. 1990; 52 878-888.

83. Bonjour JP, Carrie AL, Ferrari S, Clavien H, Slosman D, Theintz G, et al. Calcium-enriched foods and bone mass growth in prepubertal girls: a randomized, double-blind, placebo-controlled trial. J Clin Invest. 1997; 99: 1287-1294.

84. Johnston CC, Miller JZ, Slemenda CW, Teresa KR, Siu H, Joe C, et al. Calcium supplementation and increases in BMD in children. New England Journal of Medicine. 1992; 327: 82-87.

85. Lee WT, Leung SS, Wang SH, Xu YC, Zeng WP, Lau J, et al. Double-blind, controlled calcium supplementation and bone mineral accretion in children accustomed to a low-calcium diet. Am J Clin Nutr. 1994; 60: 744-750.

86. Lee WT, Leung SS, Leung DM, Tsang HS, Lau J, Cheng JC. A randomized double-blind controlled calcium supplementation trial, and bone and height acquisition in children. Br J Nutr. 1995; 74: 125-139.

87. Stear SJ, Prentice A, Jones SC, Cole TJ. Effect of a calcium and exercise intervention on the bone mineral status of $16-18$-y-old adolescent girls. Am J Clin Nutr. 2003; 77: 985-992.

88. Yano K, Heilbrun LK, Wasnich RD, Hankin JH, Vogel JM. The relationship between diet and BMC of multiple skeletal sites in elderly JapaneseAmerican men and women living in Hawaii. Am J Clin Nutr. 1985; 42: 877 888.

89. Fujiwara S, Kasagi F, Yamada M, Kodama K. Risk factors for hip fracture in a Japanese cohort. J Bone Miner Res. 1997; 12: 998-1004

90. Nowson CA, Green RM, Hopper JL, Sherwin AJ, Young D, Kaymakci B, et al. A co-twin study of the effect of calcium supplementation on bone density during adolescence. Osteoporos Int. 1997; 7: 219-225. 
91. Kalkwarf HJ, Khoury JC, Lanphear BP. Milk intake during childhood and adolescence, adult bone density, and osteoporotic fractures in US women. Am J Clin Nutr. 2003; 77: 257-265

92. Whiting SJ, Lemke B. Excess retinal intake may explain the high incidence of osteoporosis in northern Europe. Nutr Rev. 1999; 57: 192-195.

93. De Fu Ma, Wei Zheng, Ming Ding, Yu Mei Zhang, Pei Yu Wang. Milk intake increases BMC through inhibiting bone resorption: Meta-analysis of randomized controlled trials. e-SPEN. 2013; 8: 1-7.

94. Wosje KS, Binkley TL, Fahrenwald NL, Specker BL. High bone mass in a female Hutterite population. J Bone Miner Res. 2000; 15: 1429-1436.

95. Teegarden D, Lyle RM, Proulx WR, Johnston CC, Weaver CM. Previous milk consumption is associated with greater bone density in young women. Am J Clin Nutr. 1999; 69: 1014-1017.

96. Sentipal JM, Wardlaw GM, Mahan J, Matkovic V. Influence of calcium intake and growth indexes on vertebral BMD in young females. Am J Clin Nutr. 1991; 54: 425-428.

97. Rubin K, Schirduan V, Gendreau P, Sarfarazi M, Mendola R, Dalsky G. Predictors of axial and peripheral BMD in healthy children and adolescents, with special attention to the role of puberty. J Pediatr. 1993; 123: 863-870.

98. Gennari C. Calcium and vitamin D nutrition and bone disease of the elderly Public Health Nutr. 2001; 4: 547-559.

99. Nakamura K, Nashimoto M, Tsuchiya Y, Obata A, Miyanishi K, Yamamoto M. Vitamin D insufficiency in Japanese female college students: a preliminary report. Int J Vitam Nutr Res. 2001; 71: 302-305.

100. Michaëlsson K, Melhus H, Lemming EW, Wolk A, Byberg L. Long term calcium intake and rates of all cause and cardiovascular mortality: community based prospective longitudinal cohort study. BMJ. 2013; 346: 228.

101. Michaëlsson K, Wolk A, Langenskiold S, Basu S, Warensjo E, Melhus, et al. Milk intake and risk of mortality and fractures in women and men: cohort study. BMJ. 2014; 349: g6015.

102. Giovannucci E, Rimm EB, Wolk A, Ascherio A, Stampfer MJ, Colditz GA, et al. Calcium and fructose intake in relation to risk of prostate cancer. Cancer Res. 1998; 58: 442-447.

103. Giovannucci E, Liu Y, Stampfer MJ, Willet WC. A prospective study of calcium intake and incident and fatal prostate cancer. Cancer Epidemio Biomarkers Prev. 2006; 15: 203-210.

104. Chan JM. Dairy products, calcium, and prostate cancer risk in the Physicians' Health Study. Am J Clin Nutr. 2001; 74: 549-554.

105. Van Winckel M, Vande Velde S, De Bruyne R, Van Biervliet S. Vegetarian infant and child nutrition, Clinical practice. Eur J Pediatr. 2011; 170: 14891494.

106. Levrat-Verny MA, Coudray C, Bellanger J, Lopez HB, Demigné C Rayssiguier $\mathrm{Y}$, et al. Whole wheat flour ensures higher mineral absorption and bioavailability than white wheat flour in rats. $\mathrm{Br} \mathrm{J}$ Nutr. 1999; 82: 17-21.

107. Weaver CM, Proulx WR, Heaney R. Choices for achieving adequate dietary calcium with a vegetarian diet. Am J Clin Nutr. 1999; 70: 543S-548S.

108. Cheryan M. Phytic acid interactions in food systems. Crit Rev Food Sci Nutr. 1980; 13: 297-335.

109. Freeland-Graves J. Mineral adequacy of vegetarian diets. Am J Clin Nutr. 1988; 48: 859-862.

110. Heaney RP, Weaver CM, Recker RR. Calcium absorbability from spinach.
Am J Clin Nutr. 1988; 47: 707-709.

111. Weaver CM, Heaney RP, Nickel KP, Packard PI. Calcium bioavailability from high oxalate vegetables: Chinese vegetables, sweet potatoes, and rhubarb. Journal of Food Science. 1997; 62: 524-525.

112. Heaney RP, Weaver CM. Calcium absorption from kale. Am J Clin Nutr. 1990; 51: 656-657.

113. Weaver CM, Heaney RP, Proulx WR, Hinders SM, Packard PT. Absorbability of calcium from common beans. Journal of Food Science. 1993; 58: 14011403.

114. Heaney RP, Weaver CM, Hinders SM, Martin B, Packard PT. Absorbability of calcium from brassica vegetables: broccoli, bok choy, and kale. Journal of Food Science. 1993; 58: 1378-1380.

115. Maierhofer WJ, Lemann J, Gray RW, Cheung HS. Dietary calcium and serum 1,25- $(\mathrm{OH}) 2$-vitamin $\mathrm{D}$ concentrations as determinants of calcium balance in healthy men. Kidney Int. 1984; 26: 752-759.

116. Greger JL, Baligar P, Abernathy RP, Bennett OA, Peterson T. Calcium, magnesium, phosphorus, copper, and manganese balance in adolescent females. Am J Clin Nutr. 1978; 31: 117-121.

117. Wisker E, Nagel R, Tanudjaja TK, Feldheim W. Calcium, magnesium, zinc, and iron balances in young women: effects of a low-phytate barley-fiber concentrate. Am J Clin Nutr. 1991; 54: 553-559.

118. Begum A, Pereira SM. Calcium balance studies on children accustomed to low calcium intakes. Br J Nutr. 1969; 23: 905-911.

119. Wynckel A, Hanrotel C, Wuillai A, Chanard J. Intestinal calcium absorption from mineral water. Miner Electrolyte Metab. 1997; 23: 88-92.

120. Heaney RP. Absorbability and utility of calcium in mineral waters. Am J Clin Nutr. 2006; 84: 371-374.

121. Guillemant J, Le HT, Accarie C, Du Montcel ST, Delabroise AM, Arnaud $\mathrm{MJ}$, et al. Mineral water as a source of dietary calcium: acute effects on parathyroid function and bone resorption in young men. Am J Clin Nutr. 2000; 71: 999-1002.

122. Weaver CM. Calcium bioavailability and its relation to osteoporosis. Proc Soc Exp Biol Med. 1992; 200: 157-160.

123. Craig WJ, Mangels AR. Position of the American Dietetic Association: vegetarian diets. J Am Diet Assoc. 2009; 109: 1266-1282.

124.http://en.wikipedia.org/wiki/Vegetarianism_by_country \# Eupúmns.

125. White RF, Seymour J, Frank E. Vegetarianism among US women physicians. Journal of the American Dietetic Association. 1999; 99: 595-598.

126. Lea E, Worsley A. The cognitive contexts of beliefs about the healthiness of meat. Public Health Nutrition. 2002; 5: 37-45.

127. American Dietetic Association, Dietitians of Canada. Position of the American Dietetic Association and Dietitians of Canada. Vegetarian diets. Canadian Journal of Dietetic Practice and Research. 2003; 103: 748-765.

128. Sabaté J, Lindsted K, Harris RD, Johnston PK. Anthropometric parameters of schoolchildren with different life-styles. American Journal of Diseases of Children. 1990; 144: 1159-1163.

129. Papadaki A, Valsta LM, Lampi AM, Peñalvo J, Adlercreutz H, Vardavas $C$, et al. Differences in nutrient intake during a Greek Orthodox Christian fasting and non-fasting week, as assessed by a food composition database and chemical analyses of 7-day weighed food samples. Journal of Food Composition and Analysis. 2011; 24: 22-28.
Austin J Nutri Food Sci - Volume 5 Issue 3 - 2017

ISSN : 2381-8980 | www.austinpublishing group.com

Rodopaios et al. (C) All rights are reserved
Citation: Rodopaios NE, Manolarakis GE, Peppas C and Kafatos A. Is Periodic Abstinence from Dairy Products for Half a Year, Detrimental to Bone Health of Children and Adolescents?. Austin J Nutri Food Sci. 2017; 5(3): 1094. 